\title{
EKSTRAKSI SAPONIN DARI DAUN WARU BERBANTU ULTRASONIK SUATU USAHA UNTUK MENDAPATKAN SENYAWA PENGHAMBAT BERKEMBANGNYA SEL KANKER
}

\author{
Herry Santosa*, Widya Sari, Noer Abyor Handayani \\ Departemen Teknik Kimia, Fakultas Teknik, Universitas Diponegoro, \\ Jl. Prof. Soedarto, SH, Kampus Undip Tembalang, Semarang, Indonesia 50275 \\ *Email : hersantos@undip.ac.id
}

\begin{abstract}
Abstrak
Saponin adalah glikosida dengan berat molekul tinggi, sebagian tersusun dari gula yang terhubung dengan triterpen atau steroid aglikon. Saponin dapat digunakan pada berbagai bidang diantaranya perikanan, tekstil, kosmetik, dan kesehatan. Di bidang perikanan saponin digunakan sebagai pembasmi hama udang, dalam industri tekstil sebagai deterjen, dalam bidang kosmetik digunakan sebagai pembentuk busa pada sampo. Di bidang kesehatan saponin dapat digunakan sebagai penghambat pertumbuhan sel kanker. Penelitian dimaksudkan untuk mengekstraksi saponin dari daun waru dengan menggunakan bantuan ultrasonik. Lebih jauh sasaran yang diinginkan dalam penelitian ini adalah (1) menentukan variabel paling berpengaruh diantara perbandingan berat umpan tiap satuan volume solvent, ukuran bahan baku, dan frekuensi ultrasonik, (2) optimasi terhadap variabel berpengaruh tersebut untuk mendapatkan hasil terbaik.Penelitian ini dilakukan melalui 3 tahapan. Tahapan pertama dimaksudkan untuk membuat tepung daun waru. Tahap kedua dimaksudkan untuk mengekstrak tepung daun waru dalam rangka menentukan variabel paling berpengaruh dan tahap optimasi untuk menentukan kondisi operasi yang relatif baik. Tahap ketiga adalah tahap uji hasil terhadap saponin yang terekstrak. Saponin dapat diekstraksi dari daun waru menggunakan pelarut larutan 30\% berat etanol dengan bantuan ultrasonik. Ukuran daun waru merupakan variabel yang paling berpengaruh diantara perbandingan berat umpan tiap satuan volume solvent dan frekuensi ultrasonik. Ekstraksi lebih baik dilakukan pada daun waru dengan ukuran $0,2 \mathrm{~mm}$.
\end{abstract}

Kata kunci: ekstraksi, hibiscus tiliaceus, saponin, ultrasound

\section{PENDAHULUAN}

Saponin adalah glikosida dengan berat molekul tinggi, tersusun dari gula yang terhubung dengan triterpen atau steroid aglikon (Hostettmann dan Marston, 1995; Illing dkk., 2017). Definisi klasik dari saponin didasarkan pada aktivitas permukaannya; saponin memiliki sifat deterjen, memberikan busa stabil dalam air, menunjukkan aktivitas hemolitik, memiliki rasa pahit, dan beracun bagi ikan (piscicidal) (Hostettmann dan Marston, 1995). Saponin memiliki berat molekul 414,6231 gram $/ \mathrm{mol} \mathrm{dan}$ rumus molekul $\mathrm{C}_{27} \mathrm{H}_{42} \mathrm{O}_{3}$. Saponin memiliki titik didih yang cukup tinggi, hingga mencapai $158^{\circ} \mathrm{C}$ dan densitas $0,5 \mathrm{~g} / \mathrm{cm}^{3}$ pada suhu $20^{\circ} \mathrm{C}$. Saponin dapat larut dalam berbagai pelarut seperti air, etanol dan juga metanol. Beberapa juga dapat larut dalam eter, kloroform, benzena, etil asetat atau asam asetat (Hostettmann dan Marston, 1995; Tambe dan Bhambar., 2016; Bata dan Rahayu, 2017).

Saponin dapat digunakan pada berbagai bidang diantaranya perikanan, tekstil, kosmetik, dan kesehatan. Di bidang perikanan saponin digunakan sebagai pembasmi hama udang (Musalam dan Yuliana, 1989), dalam industri tekstil sebagai deterjen, dalam bidang kosmetik digunakan sebagai pembentuk busa pada sampo (Aghel dkk., 2007 ; Thoha dkk., 2009). Di bidang kesehatan saponin dapat digunakan sebagai penghambat pertumbuhan sel kanker (Arcuri, 2004; Bachran dkk., 2014).

Saponin sebagian besar terdapat dalam tanaman, baik tanaman budidaya maupun tanaman liar. Salah satu diantaranya adalah pohon waru (Hibiscus tiliaceus). Pada pohon waru, saponin terdapat baik dalam daun maupun akar. Kadar saponin pada daun waru $12,9 \mathrm{mg} / \mathrm{g}$ (Istiqomah dkk., 2011).

Saponin memiliki berat molekul yang relatif besar dan polaritas yang tinggi, karenanya isolasi saponin menimbulkan tantangan tersendiri. Masalah utama yang ada pada isolasi saponin adalah adanya campuran kompleks dari senyawa lain yang mempunyai sifat seperti saponin. Menurut Hostettmann dan Marston (1995) secara umum isolasi saponin dilakukan dengan 2 cara, yaitu dengan cara ekstraksi dan dengan cara kromatografi. Penelitian mengenai isolasi saponin telah banyak dilakukan. Penelitian terdahulu umumnya menggunakan metode kromatografi kolom dan kromatografi lapisan tipis dengan menggunakan solvent 
metanol seperti yang sudah dilakukan oleh Rahayu (2009). Bogoriani (2008) melakukan isolasi saponin dengan menggunakan metode ekstraksi maserasi. Penelitian menggunakan metode ekstraksi berbantu ultrasonik telah dilakukan oleh Wu dkk.(2001) dan Garreton dkk.(2011) tetapi bahan baku yang digunakan sertavariabel kendali berbeda.

Berdasarkan latar belakang di atas maka penelitian untuk mengisolasi saponin perlu ditindaklanjuti dengan menggunakan bahan baku yang berbeda dan variabel berpengaruh terhadap keberhasilan proses ekstraksi dengan ultrasonik perlu diperluas.

Penelitian ini bertujuan untuk menentukan variabel yang paling berpengaruh diantara variabel berat umpan tiap satuan volume solvent, ukuran umpan (diameter), dan frekuensi ultrasonik serta optimasi nilai variabel yang paling berpengaruh untuk mendapat saponin yang terekstrak paling optimal. $n$ dkk.(2011) tetapi bahan baku yang digunakan sertavariabel kendali berbeda.

Berdasarkan latar belakang di atas maka penelitian untuk mengisolasi saponin perlu ditindaklanjuti dengan menggunakan bahan baku yang berbeda dan variabel berpengaruh terhadap keberhasilan proses ekstraksi dengan ultrasonik perlu diperluas.

Penelitian ini bertujuan untuk menentukan variabel yang paling berpengaruh diantara variabel berat umpan tiap satuan volume solvent, ukuran umpan (diameter), dan frekuensi ultrasonik serta optimasi nilai variabel yang paling berpengaruh untuk mendapat saponin yang terekstrak paling optimal.

\section{METODOLOGI}

\subsection{Bahan}

Bahan baku untuk penelitian ini adalah daun waru, ethanol $94 \%$, dan air suling. Daun waru didapat daridaerah Papandayan, Gajahmungkur, Semarang. Ethanol 94\% didapat dari PT Brataco Semarang. Air suling diperoleh dari Mer-C Laboratorium Terpadu Universitas Diponegoro Semarang.

\subsection{Rancangan Penelitian}

Untuk menjawab tujuan, penelitian dilakukan dalam 3 tahapan:

$\begin{array}{ll}\text { 1. } & \text { Tahap persiapan } \\ \text { 2. } & \text { Tahap ekstraksi } \\ \text { 3. } & \text { Tahap uji hasil }\end{array}$

2.3. Tahap persiapan.

Tahap persiapan dimaksudkan untuk :

1. Membuat tepung daun waru dengan ukuran $<0,106 \mathrm{~mm}$ serta $0,5125 \mathrm{~mm}$.

2. Membuat larutan $30 \%$ berat etanol dalam air dari etanol konsentrasi $94 \%$ dan aquadest.

\subsection{Tahap ekstraksi.}

Tahap ekstraksidimaksudkan untuk :

1. Menentukan variabel yangpaling berpengaruh diantara perbandingan berat umpan tiap satuan volume solvent, ukuran bahan baku, dan frekuensi ultrasonik dengan factorial design quicker method.

2. Optimasi variabel yang paling berpengaruh.

\subsection{Penentuan variabel paling berpengaruh.}

Pada proses ektraksi saponin dari daun waru, digunakan metode ultrasonik. Tepung daun waru yang sudah dicampurkan dengan larutan $30 \%$ berat etanol kemudian diekstraksi dengan ultrasonik pada temperatur $30^{\circ} \mathrm{C}$ selama 30 menit. Variabel yang divariasikan yaitu perbandingan berat umpan tiap satuan volume solvent, ukuran bahan baku, dan frekuensi ultrasonik.

\subsection{Optimasi variabel yang paling berpengaruh}

Percobaan dilakukan pada kondisi tetap perbandingan berat umpan tiap satuan solvent 1:60, power ultrasonik $20 \mathrm{kHz}$, temperatur $30^{\circ} \mathrm{C}, 30$ menit. Variabel yang divariasikan yaitu ukuran daun waru.

\subsection{Analisis saponin}

Pada setiap akhir percobaan dilakukan uji hasil terhadap saponin yang terekstrak. Uji kuantitatif dilakukan dengan menggunakan spektrofotometer uv-vis. Dalam bentuk lain rancangan percobaan disetiap tahapan dapat dilihat pada Gambar 1. 

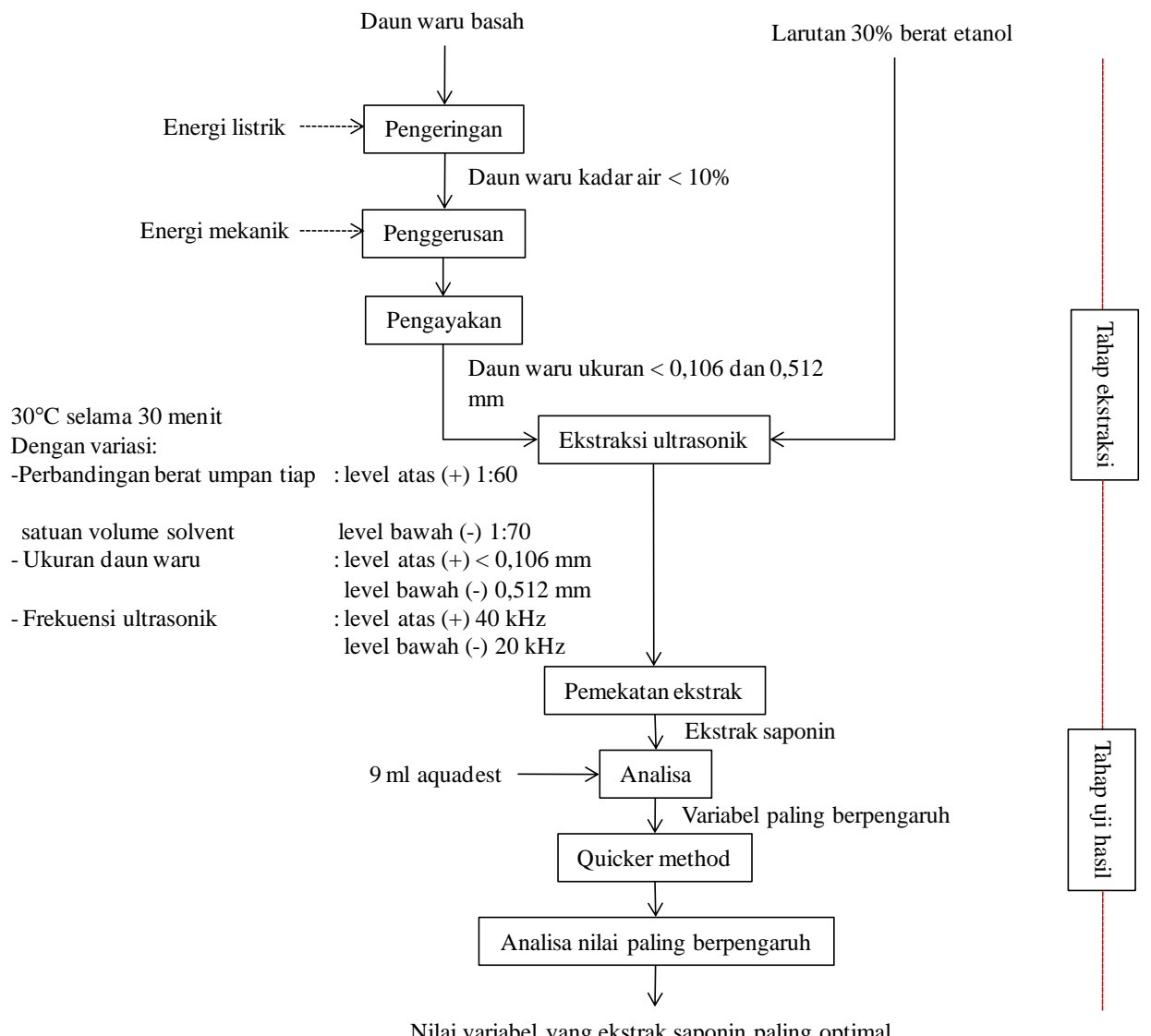

\section{Gambar 1. Skema penelitian}

\section{HASIL DAN PEMBAHASAN}

Hasil penelitian dalam rangka untuk menentukan variabel yang paling berpengaruh di antara perbandingan berat umpan tiap satuan volume solvent, ukuran daun waru, dan frekuensi ultrasonik disajikan dalam Tabel 1. Data hasil penelitian selanjutnya digunakan untuk menghitung nilai efek variabel paling berpengaruh dengan menggunakan factorial design quicker method. Hasil perhitungan efek disetiap variabel dan kombinasi antar variabel disajikan dalam Tabel 2.

\section{Tabel 1. Hasil penelitian}

\begin{tabular}{llll}
\hline $\begin{array}{l}\text { Variabel perbandingan berat umpan tiap } \\
\text { satuan volume solvent } \\
(\mathrm{g} / \mathrm{ml})\end{array}$ & $\begin{array}{l}\text { Variabel ukuran daun } \\
\text { waru } \\
(\mathrm{mm})\end{array}$ & $\begin{array}{l}\text { Variabel } \\
\text { frekuensi } \\
\text { ultrasonik } \\
(\mathrm{kHz})\end{array}$ & $\begin{array}{l}\text { Saponin } \\
\text { terekstrak } \\
(\mathrm{mg} / \mathrm{g})\end{array}$ \\
\hline $1: 60$ & $<0,106$ & 40 & 26,41 \\
$1: 60$ & 0,5125 & 40 & 14,13 \\
$1: 70$ & $<0,106$ & 40 & 21,48 \\
$1: 70$ & 0,5125 & 40 & 11,49 \\
$1: 60$ & $<0,106$ & 20 & 20,09 \\
$1: 60$ & 0,5125 & 20 & 14,01 \\
$1: 70$ & $<0,106$ & 20 & 21,57 \\
$1: 70$ & 0,5125 & 20 & 11,82 \\
\hline
\end{tabular}

\subsection{PenentuanVariabel Berpengaruh \\ yang Paling}

Pengaruh dari suatu variabel terhadap respon ditentukan berdasakan nilai efek yang didapat. Pada penelitian ini respon yang diharapkan adalah meningkatnya saponin yang terekstrak. Tanda positif $(+)$ menunjukkan adanya pengaruh positif terhadap saponin yang terekstrak, sedangkan tanda negatif(-) menunjukkan pengaruh negatif terhadap saponin yang terekstrak. Sehingga semakin besar nilai positif (+) sebuah efek, maka semakin berpengaruh variabel tersebut. 
Tabel 2. Perhitungan nilai efek variabel operasi

\begin{tabular}{|c|c|c|c|c|c|c|c|c|c|}
\hline \multirow{2}{*}{$\begin{array}{l}\text { Variabel } \\
\text { perbanding } \\
\text { an berat } \\
\text { umpan tiap } \\
\text { satuan } \\
\text { volume } \\
\text { solvent } \\
\text { F/S } \\
(\mathrm{g} / \mathrm{ml})\end{array}$} & \multirow[b]{2}{*}{$\begin{array}{l}\text { Variabel } \\
\text { ukuran } \\
\text { daun } \\
\text { waru } \\
\text { M } \\
(\mathrm{mm})\end{array}$} & \multirow[b]{2}{*}{$\begin{array}{l}\text { Variabel } \\
\text { frekuensi } \\
\text { ultrasonik } \\
\mathbf{F} \\
(\mathrm{kHz})\end{array}$} & \multicolumn{3}{|c|}{ Efek utama } & \multicolumn{4}{|c|}{ Efek interaksi } \\
\hline & & & F/S & M & $\mathbf{F}$ & F/S M & F/SF & M F & F/S M F \\
\hline $1: 60$ & $<0,106$ & 40 & $+26,41$ & $+26,41$ & $+26,41$ & $+26,41$ & $+26,41$ & $+26,41$ & $+26,41$ \\
\hline $1: 60$ & 0,5125 & 40 & $+14,13$ & $-14,13$ & $+14,13$ & $-14,13$ & $+14,13$ & $-14,13$ & $-14,13$ \\
\hline $1: 70$ & $<0,106$ & 40 & $-21,48$ & $+21,48$ & $+21,48$ & $-21,48$ & $-21,48$ & $+21,48$ & $-21,48$ \\
\hline $1: 70$ & 0,5125 & 40 & $-11,49$ & $-11,49$ & $+11,49$ & $+11,49$ & $-11,49$ & $-11,49$ & $+11,49$ \\
\hline $1: 60$ & $<0,106$ & 20 & $+20,09$ & $+20,09$ & $-20,09$ & $+20,09$ & $-20,09$ & $-20,094$ & $-20,09$ \\
\hline $1: 60$ & 0,5125 & 20 & $+14,01$ & $-14,01$ & $-14,01$ & $-14,01$ & $-14,01$ & $+14,01$ & $+14,01$ \\
\hline $1: 70$ & $<0,106$ & 20 & $-21,57$ & $+21,57$ & $-21,57$ & $-21,57$ & $+21,57$ & $-21,57$ & $+21,57$ \\
\hline $1: 70$ & 0,5125 & 20 & $-11,82$ & $-11,82$ & $-11,82$ & $+11,82$ & $+11,82$ & $+11,82$ & $-11,82$ \\
\hline \multicolumn{3}{|c|}{ Perhitungan efek } & 2,07 & 9,53 & 1,51 & $-0,34$ & 72 & 1,61 & ,49 \\
\hline
\end{tabular}

Berdasarkan Tabel 2 nilai efek positif terbesar $(+9,53)$ pada efek variasi ukuran daun waru. Sehingga dapat disimpulkan bahwa variabel operasi yang paling berpengaruh adalah ukuran daun waru. Oleh karena itu, ukuran daun waru perlu divariasikan.

\subsection{Optimasi Variabel Paling Berpengaruh}

Tahap ini bertujuan untuk mengkaji dan menentukan kondisi relatif baik dari ukuran tepung daun waru berdasarkan ekstrak saponin yang didapatkan, sedangkan frekuensi ultrasonik dan perbandingan berat umpan tiap satuan volume solvent dijadikan variabel tetap.

Berdasarkan data hasil optimasi pada Gambar 2 diketahui bahwa semakin kecil ukuran daun waru maka saponin yang terekstrak semakin besar. Hal tersebut disebabkan luas permukaan kontak sangat mempengaruhi proses ekstraksi. Semakin kecil ukuran daun waru, luas permukaan bidang kontak antar fasa menjadi semakin besar maka molekul-molekul solvent lebih mudah masuk ke dalam bahan sehingga jumlah massa yang dipindahkan tiap satuan waktu menjadi semakin besar (saponin yang terekstrak semakin banyak) (Lavilla dan Bendicho, 2018).

Saponin yang terekstrak tiap gram sampel semakin meningkat tetapi peningkatan signifikan pada ukuran daun waru $0,3375 \mathrm{~mm}$ dan $0,2 \mathrm{~mm}$, sedangkan peningkatan relatif tetap pada ukuran $0,128 \mathrm{~mm}$ dan $<0,106 \mathrm{~mm}$. Pada ukuran daun waru $<0,106 \mathrm{~mm}$ saponin yang terekstrak paling banyak $(20,09 \mathrm{mg} / \mathrm{g}$ sampel). Namun untuk membuat tepung daun waru ukuran $<0,106 \mathrm{~mm}$ membutuhkan waktu 12 kali lipat lebih lama dibandingkan dengan ukuran 0,2 mm. Meskipun saponin yang diperoleh pada ukuran $<0,106 \mathrm{~mm}$ cukup besar tetapi untuk mendapatkan tepung ukuran tersebut membutuhkan waktu, tenaga, dan biaya operasi lebih besar. Sehingga dengan menggunakan waktu yang relatif singkat kapasitas produk (ukuran 0,2mm) lebih banyak. Oleh karena itu, dapat disimpulkan bahwa kondisi relatif baik ekstraksi saponin dari daun waru pada ukuran $0,2 \mathrm{~mm}$.

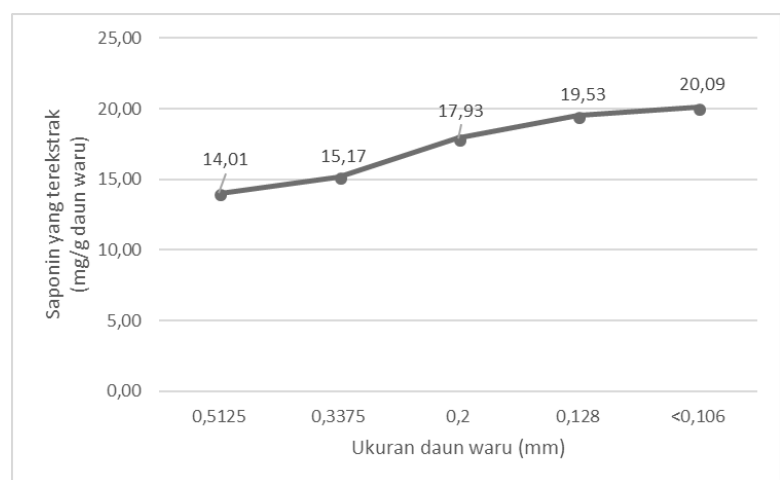

Gambar 2. Saponin yang terekstrak pada berbagai ukuran daun waru

\section{KESIMPULAN}

Saponin dapat diekstraksi dari daun waru menggunakan pelarut laruran 30\% berat etanol dengan bantuan ultrasonik. Ukuran tepung daun waru merupakan variabel yang paling berpengaruh diantara perbandingan berat 
umpan tiap satuan volume solvent dan frekuensi ultrasonik. Ekstraksi lebih baik dilakukan pada daun waru dengan ukuran $0,2 \mathrm{~mm}$.

\section{DAFTAR PUSTAKA}

Aghel, N., Moghimipour, E., and Dana, R.S., (2007), Formulation of a Herbal Shampoo using Total Saponins of Acanthopyllum squarrosum, Iranian Journal of Pharmaceutical Research, 6(3).

Arcuri P.B., (2004), Animal Science 625. Nutritional Toxicology Phenolic Toxicants,http://www.ansci.cornel.edu/co urces/ac625/625 polyphytox.html.

Bachran, C., Bachran, S., Sutherland, M., Bachran, D., and Fuchs, H., (2014), Preclinical Studies of Saponins for Tumor Therapy, Recent Advances in Medicinal Chemistry, 1, 272-302.

Bata, M., and Rahayu, S., (2017), Evaluation of Bioactive Substances in Hibiscus tiliaceus and its Potential as a Ruminant Feed Additive, Current Bioactive Compounds, 13, 157-164.

Bogoriani, N.W., (2008), Isolasi Dan Identifikasi Glikosida Steroid Dari Daun Andong ( Cordyline Terminalis Kunth ), Jurnal Kimia, 2(1), 40-44.

Garretón, L.G., Hernández, Y.V., Pacheco, M.G.C., Sainz, J., Alarcón, John., (2011), Ultrasonically enhanced extraction of bioactive principles from Quillaja Saponaria Molina, Ultrasonics 51, 581585.

Hostettmann, K. and Marston, A., (1995), Chemistry and Pharmacology of Natural Products, Saponin 1st ed., Cambridge: Cambridge University Press.

Illing,I., Safitri, W., and Erfiana, (2017), Uji Fitokimia Ekstrak Buah Dengen, Jurnal Dinamika, 66-84.

Istiqomah, L., Hardian, H., Febrisantosa, A., \& Putra, D., (2011), Waru leaf (Hibiscus tiliaceus) as saponin source on In vitro ruminal fermentation characteristic, Journal of the Indonesian Tropical Animal Agriculture, 36(1), 43-49.

Lavilla, I., andm Bendicho, C, (2018), Fundamentals of Ultrasound-Assisted Extraction. In Water Extraction of Bioactive Compounds, 291-316.
Musalam dan AYuliana, (1989), Pemanfaatan Saponin Biji Teh Pembasmi Hama Udang, Gambung : Pusat Penelitian Perkebunan,.

Rahayu, I.D., (2009), Isolasi Dan Identifikasi Saponin Dari Aloe Barbadensis Miller Sebagai Antibiotik Alami : Penanggulangan Mastitis Pada Sapi Perah. Gamma, 1, 28- 33.

Tambe, V. D., and Bhambar, R. S., (2016), Studies on diuretics and laxative activity of the Hibiscus tiliaceus Linn. bark extracts. International Journal of PharmTech Research, 9(3), 305-310.

Thoha, M.Y., ASitanggang, A.F., Hutahayan, D.R. S., (2009), Pengaruh Pelarut Isopropil Alkohol 75\% dan Etanol 75\% terhadap Ekstraksi Saponin dari Biji Teh dengan Variabel Waktu dan Temperatur, Jurnal Teknik Kimia, 16(3).

Wu, J., Lin, L., and Chau, F. T., (2001), Ultrasound-assisted extraction of ginseng saponins from ginseng roots and cultured ginseng cells, Ultrasonics sonochemistry, 8(4),347-352. 